Mrs. A.L. Combrink

Department of English

IHIE COMIC VISION

IN CON'TEMPORARY BRITISH DRA.MA*

There has long been controversy as to the necessity and validity of generic distinctions in literature, especially dramatic literature. Some of the carliest critical comment on literature was concerned with generic distinction and as Aristotle's ideas (the earliest extant critical comment on litcrary genre) were firmly based on a study of plays performed at the time it would seem that he recognized that a generic type represented a particular attitude and vision of life on the part of the author.

Martin Ksslin (1978, p. 76) has suggested that "the theory of genres deals with abstract concepts of great importance and purity. Its study is essential for anyone who wants to understand drama and through it human nature itsclf". While this is still a very abstract view, Heilman $(1978$, p. 7$)$ has made a more useful suggestion. According to him the study of genre is a way into the play, and if one accepts that comedy is the expression of a particular vision of life and of society, then an understanding of what a particular genre implies (both as to form and content) will be a valuable way into the play, an understanding of the way in which particular concretion of reality functions.

A cautionary note should be sounded. In the first place it would be totally wrong to insist pedantically on a "pure" definition of comedy. This is just not possible in dealing with something as varied and diverse as literature. Thus any theoretician will tread cautiously and suggest and describe rather than to prescribe.

Comedy presents the definer with seemingly insuperable difficulties. Various critics from Samuel Johnson onwards have commented on this fact. The comic vision is an all-encompassing onc, dealing with man in the entirety of his existence. It looks at all his weaknesses and foibles and ironically exposes them. It deals also with man in his social interrelatedness rather than in his private agony (which is the domain of tragedy). Because this vision is so encompassing, and because the field is so illimitably wide

* Paper read at the Association for Language and Literature, PU for CHE, Junc, 1979. 
and varied, visions on it can scem to be impossibly diverse and fragmented. The theorist dealing with comedy is therefore faced with a double task. In the first place he has to isolate and identify the components of what Heilman (1978) has called the "permanent ways" of comedy (which will be indicated later as constituting the traditional view of comedy). In the second place he has to be alert to the appearance of elements that can be characterized as constituting the "variable superstructure" of comedy created by changing fashions and ideas among the members of the society from which it naturally arises.

Potts (1949) has stated that the chief difficulty in any attempt to discover the character of comedy by inductive methods is the selection of specimens from which to generalize; for we cannot make the selection without first forming a notion of comedy to guide us in making it.

Thus, on the basis of a survey of literature some notion of comedy has been established. The ideas most commonly held by theorists from Aristotle to Ileilman (1978) and Davis (1979) have been examined. The study has yiclded the impression that there are certain main areas of interest which should be looked at in the process of arriving at a valid idea of what constitutes comedy. The various areas of concern together with an indication of what is gencrally thought in each instance will be briefly indicated.

Before proceeding to this consideration, however, an important distinction should be made. Contrary to popular belief, comedy is not a synonym for laughter. Laughter theory and comic theory have become almost inextricably entangled, and while it would be unnecessarily pedantic to cxclude any consideration of laughter from a consideration of the comic, one has to tread very warily. Heilman has cautiously advised that laughter should be regarded as a frequent symptom of the comic. Generally speaking, however, laughter theory has no place within comic theory - if it should be given too much prominence it would constitute an invasion into the field of literary theory by a concern which would more properly be at home in psychology and physiology. Thus, the most that should be said would be that laughter is an inessential adjunct of comedy.

To deal then with the permanent ways of comedy. It has been established that the comic flourishes only in society, that the world constitutes the comic realm and that comedy consists in the implicit or explicit examination and revelation of relationships between men and between men and socicty. Comedy is intrinsically a social form as opposed to the lone individuality of most tragic heroes.

Within this comic realm. the world, there is always a keen awareness of the disparateness of reality. I.ssential incongruities abound and create the 
ironic underpinning that determines the character of many great comedies. The ironic principle is implicit in man's perceptive response to the world he inhabits. The disparate is to be found both in man and in the world that constitutes the realm of comedy.

Many critics hold that emotion is a foe to comedy, that pure reason best apprehends what is seen as a dispassionate approach to life and to man. It is true that this intellectualized vision holds true of many comedies of $\mathrm{man}$ ners but that it is not a prerequisite for the comic. It is true, however, that an attitude of ironic detachment is an aid to greater perceptiveness in all relationships, but this detachment need not be total or misanthropic.

A constant in earlier criticism of comedy has been the idea of reduction, morality and correction. More recent criticism has mellowed this view to the extent that it has practically disappeared from serious comic theory. What has remained is the faintly utilitarian view that comedy, in revealing man's foibles and weaknesses, is an aid to understanding and insight into man's essential condition. This intention is now seen, however, as heuristic rather than moralistic as it need not lead to improvement or reformation. By the same token, then, satire is seen to be a very narrow segment of the truly comic, seeing that the satiric vision is baleful rather than compas. sionate.

The idea of compassion is an important one in true comedy, even to the modern, bleak variety. It implies the acknowledgement and the sharing of pain, of the agony of being alive and being in constant, even abrasive contact with one's fellowmen.

Comedy's searingly accurate vision of the limited and imperfect aspects of reality is another important consideration. The vision of great comedy is clear and unblinkered, a merciless revelation of every cherished foible and weakness that man is heir to. It is essential to note that even though this revelation may induce laughter in the audience, the laughter is not in any way to be regarded as a real or potential scourge - it is simply a probable effect of man's (shocked) realization of his kinship with imperfection.

What is significant is that the awareness of limitation within the confines of the play should be implicitly accompanied by acceptance and insight. In this context, Heilman (1978) has spoken of both acceptance and overacceptance: the over-accepting attitude being a concomitant of the contemporary comic vision. The over-accepting attitude will also be seen later to be intrinsically linked to the non-redemptive mode of contemporary comedy.

It has been argued that comedy has a ritual or mythic substructure. While this approach may be useful to establish interpretive parallels, it does not 
add essentially to our understanding of the nature of comedy.

Traditional comedy, created within the spiritual framework of the Christian world view, reveals a pattern of symbolic redemption withint the total structure of the play that has long existed as an essential feature of comedy. Increasingly, however, in comcdies written in the course of the present century in Britain the aspect of redemption has been eroded to the extent that it has now virtually disappcared. The prevailing world view in Western Europe has to be seen as the prime reason for this bleakness that is now a pervasive quality. Therefore, comedy is increasingly being used as a means to translate the despair afflicting significant numbers of people in the modern world.

The image of the abyss, the void, has suddenly become an apt one to evoke the situation in which modern man has become entrapped.

1 arce as a dramatic device to translate irrationality has become peculiarly suitable to modern dramatists. From its much maligned position as a dis reputable low-class cousin of comedy farce has gained new artistic validity, particularly because the violence and aggression of the farcical mode is a very apt idiom in the twentieth century.

By the same token, tragedy has declined - in direct proportion to the loss of gods man has become incapable of attaining passionate grandeur and has settled instead for a tattered dignity, agonisingly evoked in the language and images of disintegration.

When the foregoing abstractions are translated into formal terms, one finds that traditionally

(a) comic characters are everymen, representing imperfect and fallible humanity;

(b) comic plots are often improbable. In comedy the stress is not on coherent plot structure but on the effective creation of a number of situations in which characters are shown to respond to other people in a social context. In traditional comedy the characters are usually exposed to a great many difficulties and only come to terms with the social situation after many trials and tribulations. During this period insight is gained and acceptance developed. The traditional happy ending, symbolized by a wedding, is often artificial but is conventionally required;

(c) language is one of the strong points of comedy - but the language of so. cial interaction, not the language of soul searching, is used; and

(d) comic themes usually have some social significance and are usually cveryday concerns, not lofty moral problems. In bricl, comic themes usually centre on sex, money and politics. 
A notion of comedy has thus been established and serves as an aid to the selection of specimens upon which to base a descriptive and inductive theory of comedy valid for the present age.

The contemporary British playwright, Tom Stoppard, will be discussed as a representative of the new comic vision in British drama, and some deductions made from his work which might be regarded as valid in the framework of contemporary British drama.

\section{Tom Stoppard}

Stoppard has been called a serious joker - his work can be regarded as an ironic joke designed to penetrate to the marrow, a farce in which discussions about art and life are subordinated to questions about the nature of reality itself. Stoppard himself has said on one occasion that he wants to demonstrate that he can make serious points by flinging a custard pie around the stage for a couple of hours. In the course of another interview he asserted that he considers his dramatic work a means of withdrawing with style from chaos.

These remarks to a large extent typify his work. He poses the most serious questions about the nature of reality, the loss of identity, the contingent and relative nature of truth, the loss of mystery, intuition and wonder, and the total and terrifying dislocation of the familiar and comforting dimensions of time and place. He achieves his dramatic ends by exquisite characterization, the judicious use of the farcical as a device and through language full of allusive and suggestive power. In fact, in Stoppard's work the elegance of his language represents an imposed order on the wild disorder teeming underneath the surface. Language is thus a device for kecping an awareness of cosmic homelessness at bay.

Two of his plays might be regarded as seminal. In Rosencrantz and Guildenstern Are Dead he illustrates the theme of the loss of identity of modern man by using the two most peripheral charactars in Hamlet. There is a very effective theatricality at work in the play - one could well imagine Hamlet being performed on an adjacent stage. The play gains immensely in power if one knows Hamlet well, as the allusions are basically to the best-known of Shakcspeare's plays. In using Hamlet, the playwright succeeds in greatly enriching his own play through the allusive framework provided by the other play.

Rosencrantz and Guildenstern are the eternal little men. At the mercy of a corrupt government, they battle on valiantly, forcver out of their depth, forever trying desperately to adjust to the demands of socicty. They are in 
mortal terror because the ordinary natural laws have become suspended (as appears from the wildly improbable result of the games of chance they play with coins). They lament the loss of mystery, intuition and wonder (Guildenstern wistfully remarks that "It would have been nice it if had been a unicorn" - the mythical beast with one horn in the centre of its forehead, representing mystery). When they finally accompany Hamlet to England they find out well in advance about the terrible fate awaiting them, but they go on. They are caught incxtricably in a web they cannot see and cannot understand but which ultimately they have to accept. They do accept with a curiously forlorn dignity. Perhaps, even, they will gain a fixed identity once they are dead and written into history.

Established truth disappears - instead, truth now becomes only that which one believes to be true. This awareness induces selfpity in them, until the Player scornfully tells them that "uncertainty is the normal state. You're nobody special". 'This is the point - they're also nowhere special for "we came from roughly south according to the rough map", and now they are "slipping of the map" in what they regard as "a conspiracy of cartographers". Finally, Rosencrantz declares tiredly that he has had enough, for, "to tell you the truth, I am relieved". These little men, not knowing the ins and outs of their hostile surroundings, moving idly on towards eternity without "possibility of reprieve or hope of explanation" become modern man posed precariously on the brink, never quite falling into the void but never quite redeemed and pulled back.

The play is hilariously funny in places, but every laugh is edged with hysteria. The farcical method is used with devastating effect by stoppard.

All the traditional comic clements can be found in this play cxcept the feature of grace and redemption, a phenomenon rooted in the awareness of cosmic homelessness. the broken centre, the loss of faith in anything to sus. tain oneself.

In Jumpers this pre-occupation is taken further. The main character is a Professor of Moral Philosophy who has to use concrete objects to prove religious tenets because people do not listen to and cannot understand abstract reasoning and refuse to have faith. Some broadly farcical situations result from this incongruous juxtaposition. Moore is an oddity in his world, as he wants to prove the existence of a moral absolute - he is pointed out to visicors along with the stained-glass windows in what used to be the church but is now the gymnasium. The Professor of Logic, his colleague, is also a gymnist, for this university there is a close link between gymnastics and philo. sophy with an obvious implication.

The secondary plot in this play is also-fascinating. Moore's wife Dotty 
has retired as a musical comedy star. She used to specialize in songs about the moon, but ever since the first moon-landing by Britons (who act very unchivalrously in the course of their pioneering mission) she fecls that the essential mystery of life has been violated and she succumbs to a breakdown. (lt is significant that madness or nervous breakdowns figure largely in contemporary drama - it is often felt that madness is a suitable response to the incomprehensible demands of the contemporary world.) She is accused of having killed the Professor of Logic and there is a nightmarish police inquiry. This inquiry, superimposed upon Moore's inquiry in to the possibility of a moral absolute, is very effectively used. The contingent nature of the truth is once more demonstrated through the finding of McFee's body and the bland acceptance by the police of the grotesque and improbable story told by everybody.

Other contemporary dramatists have dealt with similar topics. They have sought to express the awareness of despair which accompanies modern man by resorting to formerly taboo subjects. Peter Nichols, for example, has written plays about mental retardation and about illness and death. It would seem that many of these contemporary playwrights feel that by joking about something unspeakable they remove its sting, they become able to face it.

The characters in contemporary drama emerge as little men, confused by the world and its claims, having all too uncomfortably clear a picture of himself and his weaknesses. Throughout these plays, through the abrasive and corrosive contact with others, the characters come to a painfully clear understanding of themselves. This happens in traditional comedy as well, of course. However, what happens in traditional comedy after this process of understanding is the real acceptance, the reasoned surrender, to the claims of one's imperfection. This sort of acceptance finally allows a sort of redemption, because real acceptance implies a negotiated surrender - one accepts one's limitations but one also keeps to hope, to love and self-respect. as mediating and redeeming qualities. In this more contemporary version of the comic, however, the hero is stripped of all his pretences, and he is made aware of his limitations, but now a change occurs. I'he hero now also accepts his weaknesses, but with an excessive degree of resignation, what Ileilman (1978) has called over-acceptance. In what is often called black comedy, the main character remains, at the end of the play, in an almost catatonic stance on the edge of the abyss (in traditional comedy he is pulled back from the brink in the nick of time and redecmed), suspended for ever secmingly in his misery - yet still laughing, still retaining, because he ac. cepts all the setbacks and comes back for more, a dignity that cannot be de- 
nied. Walter Kerr (1967) has suggested with great perception that the nameless misery which modern man clings to perhaps constitutes the new pretence that ought to be ridiculed (p. 363). In most contemporary comedies man accepts (within the framework of the prevailing world view) his being the most wretched of beings. He laughs disdainfully about fundamental imperfections, but the laughter is edged with hysteria and is often abruptly truncated. He comes to a complete and bleak knowledge of himself but refuses to accept and then to forgive. The picture of modern comic man is irresistibly that of the little figure teetering on the edge of the void, the abyss. Ile has seen himself and all his weaknesses and takes a decidedly jaundiced view. He accepts, but he does not forgive - neither himself nor the world. He retains a certain tattered dignity, drawing his moral tatters close about himself, so that one responds to him because one shares his humanity and because he invites compassion. The comic hero has always been both beast and angel, and redemption was possible glimpses of the engelic kept reminding him that man does have a little claim to greatness. The contemporary hero proudly rejects the angelic and embraces the vision of himself as a "poor, bare forked animal", who is an alien in a hostile universe but who resolutely if ridiculously strives to impose some measure of intelligibility on his universe. It has been said that the vision of modernism is black, stark and implacable - comedy in this vision is harsh, and it makes no waivers. The world cannot be transcended as in the past through dependence on supernatural forces, through dependence on faith, but it is argued that some measure of transcendence is possible through an unflinching confrontation with the forces of bleakness and emptiness pervading in world made totally comfortless. Modern comic man might then be regarded as performing a macabre, funny, pathetic dance on the edge of the abyss.

\section{REFERENCES}

ESSI.IN, M. 1978. An Anatomy of Drama. London, Abams Books.

HEILMAN, R.B. 1978. The way's of the World. University of Washington Press.

KERR, W. 1967. Tragedy and Comedy. New York, Simon and Schuster.

POTTS, L,J. 1949. Comedy. London, Hutchinson.

DANS,.Jessica M. 1978. Farce. London, Methuen. 